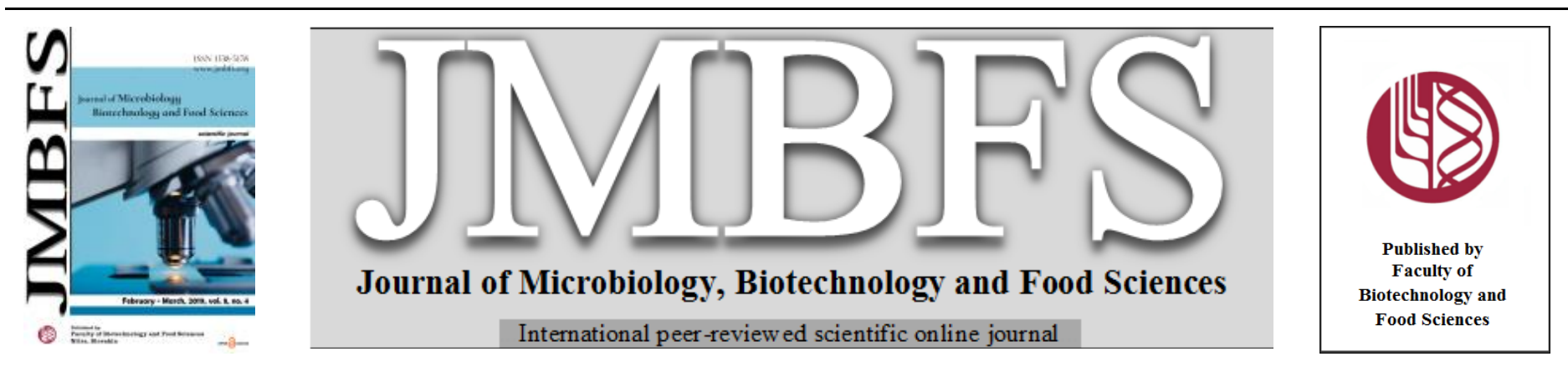

\title{
DEVELOPMENT OF BISCUITS BY PARTIAL SUBSTITUTION OF REFINED WHEAT FLOUR WITH CHICKPEA FLOUR AND DATE POWDER
}

\author{
Jyotika Dhankhar ${ }^{* 1}$, Neha Vashistha ${ }^{1}$ and Asha Sharma ${ }^{2}$ \\ Address(es): Dr. Jyotika Dhankhar, \\ ${ }^{l}$ Department of Food Science and Technology, Maharishi Dayanand University, Rohtak-124001, Haryana, India. \\ ${ }^{2}$ Department of Botany, Maharishi Dayanand University, Rohtak-124001, Haryana, India.
}

*Corresponding author: jyotika.ft@mdurohtak.ac.in

doi: 10.15414/jmbfs.2019.8.4.1093-1097

\section{ARTICLE INFO}

Received 17. 6. 2018

Revised 26. 10. 2018

Accepted 31. 10. 2018

Published 1. 2. 2019

Regular article

open $\partial$ ACcess

\begin{abstract}
The current investigation was undertaken to optimize the process for development of biscuits using composite flours prepared by addition of chickpea flour and date powder to refined wheat flour. Composite flours utilized in biscuit manufacture were obtained by mixing refined wheat flour, chickpea flour and date powder in different ratios as 100:0:0 $\left(\mathrm{T}_{0}\right)$, 80:10:10 $\left(\mathrm{T}_{1}\right)$, 60:20:20 $\left(\mathrm{T}_{2}\right)$, 40:30:30 $(\mathrm{T}$ 3) and 20:40:40 $\left(\mathrm{T}_{4}\right)$ respectively. The flours were analyzed for their physico-chemical as well as functional properties. Of all the flours studied, chickpea flour had the highest value for ash, fat and protein content as 3.30\%, $5.40 \%$ and $21.88 \%$ respectively. Date powder contained highest crude fiber content $(9.05 \%)$ but lowest protein content $(1.96 \%)$. Refined wheat flour had highest values for most functional properties like water absorption capacity (158\%), oil absorption capacity $(139.60 \%)$ and bulk density $(0.95 \mathrm{~g} / \mathrm{ml})$. Foaming capacity and LGC were observed to be highest for chickpea and date powder respectively. There was no significant difference $(\mathrm{p}>0.05)$ was observed in diameter and thickness of different biscuit samples however, spread ratio and spread factor differed significantly $(\mathrm{p}<0.05)$. Spread ratio and spread factor of biscuits increased with incorporation of chickpea flour and date powder with the value being highest for highest level of substitution. Sugar level could be reduced up to $60 \%$ by use of date powder as sweetening agent for replacing sugar. Overall acceptability scores of biscuits revealed that substitution of chickpea flour and date powder up to $30 \%$ each for refined wheat flour was appropriate to develop acceptable biscuits.
\end{abstract}

Keywords: Biscuits, chickpea, date powder, functional properties, spread ratio, Overall acceptability

\section{INTRODUCTION}

Bakery products have served as dietary staples for the mankind from the ancient times by providing the consumers with delectable choices. Among the wide range of different bakery products available in market, biscuits represent the one of the major categories consumed by masses. Biscuits are favorite food items among large segments of population on account of being affordable, inexpensive, savory, convenient, and shelf stable (Arshad $\boldsymbol{e t}$ al., 2007). The key ingredients generally used in the manufacture of biscuits are flour, sugar and fat. Biscuits may be enriched with other ingredients to improve upon their nutritional value. The incorporation of ingredients like proteins, vitamins, mineral, fibers etc. into the basic formulation can enhance the nutritional as well as sensory quality of cookies. Generally, biscuits are characterized not only by low content of protein, vitamins, dietary fiber and minerals but also contain high amount of sugar and fat; making them not so healthy option for consumers. This has led to introduction of concept of composite flour that represents the flour obtained by blending different flours derived from cereals, roots and tubers, legumes etc. with or without the addition of wheat flour (Adeyemi and Ogazi, 1985). There are many flours which can be used as base materials for the formulation of composite flours like rice flour, barley flour, oat flour, chickpea flour, date powder, pumpkin peel powder etc.

Chickpea (Cicer arietinum L.) is the one of the most widely consumed as well as cultivated legume crops across the world. Within India, chickpea represents one of the most cultivated crops occupying almost $35 \%$ of total area under cultivation for pulses (Purushothamana et al., 2014). Chickpea contains high level of nutrients like fibers, proteins, minerals and natural polyphenols (Singh, 1985). It is rich source of high digestibility proteins, good source of essential amino acid lysine; is relatively free of anti-nutritional factors and protein content is nearly twice as much present in wheat flour (Muller, 1983). It exhibits low glycaemic index due to high amount of complex carbohydrates and has dietary fiber content almost three times than that of wheat flour (Sathe et al., 1983). It possesses numerous vitamins like riboflavin, thiamine, niacin, folate and the vitamin A precursor, $\beta$-carotene. It is also a good source of minerals like $\mathrm{Ca}, \mathrm{P}, \mathrm{Fe}, \mathrm{Mg}$ and
$\mathrm{K}$ and unsaturated fatty acids such as oleic acid and linoleic acid (Jukanti $\boldsymbol{e t}$ al. 2012). Chickpea has been reported to decrease incidence of diseases like diabetes, cardiovascular disease, cancer and some digestive diseases (Jukanti et al., 2012).

Date palm (Phoenix dactylifera L.) is a sweet edible fruit belonging to the family Arecaceae. Dates have low fat content, and are therefore, suitable for hear patients who can consume dates as such or their products in different forms (Panda, 2001). Carbohydrate content in dates is quite high $(70 \%)$ and is predominated by sugars. Generally, invert sugar is the main sugar present in dates which is comprised of glucose and fructose. Glucose is beneficial as it represents the most readily available source of energy (Myhara et al., 1999; Liu et al., 2000). Fructose on account of being sweeter than glucose (almost two times) generates the feeling of fullness in consumer and thereby decreases the calorie intake in comparison to fat rich diet. Date fruits are energy dense food sources Dates have low percentage of fat $(0.2$ to $0.5 \%)$; high level of protein (2.3 to $5.6 \%$ ), vitamins and a good source of dietary fiber $(6.4$ to $11.5 \%)$. Date fruits are good sources of minerals like of selenium, copper, potassium, and magnesium and also contain high levels of phenolic compounds and antioxidants (Iftikhar $\boldsymbol{e t}$ al., 2015). Dates have been shown to mitigate the effect of hypertension, hyperglycemia and hyperlipidemia in diabetic patients (Appel et al., 1997).

Biscuits are the bakery products widely consumed by most of the people but are lacking in several nutrients including some vitamins, minerals, fiber and protein. Due to high level of protein in chickpea and high fiber as well as mineral content in date powder, both of them could complement each other for preparation of composite flour and hence, enhance the nutritive value of biscuits. Furthermore, the use of date powder as sweeting agent is promising alternative for sugar addition in biscuits. So biscuits with refined wheat flour, chickpea flour and date powder offer a reliable solution for producing biscuits with higher protein and fiber content.

Therefore, the current study was aimed at optimization of recipe for development of biscuits by partial replacement of refined wheat flour with chickpea flour and date powder; date powder was also optimized to serve as a sweetening agent. 


\section{MATERIALS AND METHODS}

Basic raw material required for preparation of biscuits viz., refined wheat flour, chickpea flour, sugar, fat, baking powder etc., were purchased from local market in Rohtak. Dried dates were purchased from local market and cleaned; further dried in oven for 6-7 hours at $60^{\circ} \mathrm{C}$. After cooling dried dates were ground and passed through $20 \mathrm{~mm}$ mesh sieve to obtain fine powder.

\section{Preparation of composite flours}

Composite flour was prepared in five compositions $\left(\mathrm{T}_{0}\right.$ to $\left.\mathrm{T}_{4}\right)$ with refined whea flour, chickpea flour and date powder in the ratio of 100:0:0, 80:10:10, 60:20:20, 40:30:30 and 20:40:40 respectively.

\section{Preparation of biscuits}

Biscuits were prepared as per standardized formulation with slight modification (Vatsala and Haridis Rao, 1990). A known weight of flour (100 g) and baking powder (1.5 g) were taken for dough preparation. It was mixed with fat and sugar and required amount of water was added until smooth dough was obtained. In the formulation of partially substituted biscuits, date powder was substituted for sugar in the proportionate amount. The dough was rolled out with rolling pin into flat base having $10 \mathrm{~mm}$ thickness and shaped into round form of $5 \mathrm{~cm}$ in diameter with a cutter. The biscuits were baked in laboratory oven at $180^{\circ} \mathrm{C}$ for 30 minutes Biscuits were afterwards taken out of oven, cooled \& kept in an air tight package for further studies.

\section{Analytical methods}

The crude protein in the samples of flour and cookies was estimated according to Kjeldhal nitrogen estimation as described in AACC method (2000). Moisture content was estimated in flour sample and cookies using AOAC method (1999). The ash content was calculated as per AOAC method (2000) and crude fiber was estimated as per AOAC standard method (1995).

\section{Functional properties of flour}

\section{Water and oil absorption capacity of flour}

The water and oil absorption capacities (WAC and OAC) were evaluated as per method given by Sosulski et al. (1976). Different flour samples were weighed accurately $(1 \mathrm{~g})$ each in separate weighing dishes and made into suspensions by mixing with $10 \mathrm{ml}\left(\mathrm{V}_{1}\right)$ of distilled water or refined soybean oil. Suspensions were aged for $30 \mathrm{~min}$ and centrifuged at $2200 \mathrm{~g}$ for $10 \mathrm{~min}$. After centrifugation, the supernatant was poured into a $10 \mathrm{ml}$ graduated cylinder, and the volume was noted as $\left(\mathrm{V}_{2}\right)$. Water absorption was evaluated as $\mathrm{ml}$ of water bound per gram flour and was expressed as percentage of water bound by flour sample.

\section{$\operatorname{WAC}(\%)=$}

$$
\frac{\mathrm{V} 1-\mathrm{V} 2 \times 100}{\text { weight of Sample }}
$$$$
\text { (1) }
$$

Oil absorption capacity was evaluated as $\mathrm{ml}$ of oil bound per gram flour. The absorbed oil was expressed as the percentage of oil bound by sample.

$$
\text { OAC }(\%) \quad=\quad \frac{\mathrm{V} 1-\mathrm{V} 2 \times 100}{\text { weight of Sample }}
$$

\section{Bulk density of flour}

The bulk density of flour was determined as per Okaka and Potter (1977) method. $50 \mathrm{~g}$ of each flour sample was filled in a $100 \mathrm{ml}$ graduated cylinder and tapped for specified number of times (20-30). The volume finally attained after the tapings was noted and bulk density was determined as weight per unit volume of sample.

\section{Swelling capacity (SC) and water solubility index (WSI)}

The swelling power of samples was determined by the method Schoch (1964). 15 $\mathrm{ml}$ of distilled water was mixed with $1 \mathrm{~g}$ of each flour sample and shaken to form suspension. Suspensions formed were then kept in water-bath at $80^{\circ} \mathrm{C}$ for $30 \mathrm{~min}$ and then submitted to centrifugation at $3000 \mathrm{rpm}$ for $10 \mathrm{~min}$.

Swelling capacity $=$

weight of sediment $x 100$

\section{Foaming capacity and foaming stability of flour}

Foaming capacity and foaming stability were estimated according to Narayana and Narasinga Rao (1982). $50 \mathrm{ml}$ distilled water was mixed with $1 \mathrm{~g}$ of sample in a graduated cylinder at $30 \pm 20^{\circ} \mathrm{C}$ and vortexed for 5 min to cause foaming.

$$
\mathrm{FC}=\frac{\text { volume of foam }(\mathrm{AW})-\text { volume of foam }(\mathrm{BW})}{\text { volume of foam }(\mathrm{BW})} \times 100
$$

\section{Least gelation concentration}

Coffman and Garcia (1977) method with slight modification was used for determination of least gelation concentration. Different flour dispersions of 2,4 , $6,8,10,12,14,16,18,20,22$ and $30,32,34 \%(w / v)$ were made with $5 \mathrm{ml}$ of distilled water and incubated at $90^{\circ} \mathrm{C}$ for $1 \mathrm{~h}$ in a water bath. Samples were then cooled under tap water and left undisturbed for $2 \mathrm{~h}$ at $10 \pm 20^{\circ} \mathrm{C}$.

\section{Physical analysis}

Diameter was calculated by placing three biscuits side by side and rotating them $90^{\circ}$. The diameter was again measured for three biscuits $(\mathrm{cm})$ and mean value was obtained. Thickness was evaluated by keeping 3 biscuits one over another and recording the mean value of such two observations. Spread ratio was determined by dividing mean diameter value of biscuits by mean thickness of biscuits. Weight of biscuits was calculated as average weight of four biscuits weighed individually.

\section{Sensory analysis}

Sensory analysis of biscuits was done by a group of 8 semi trained members with a 9-point hedonic scale in accordance with Ranganna (1986). The biscuits were analysed for their flavor, color, appearance, texture and overall acceptability.

\section{Statistical analysis}

Statistical analysis of data was carried out using one-way analysis of variance (ANOVA) with three replications in a randomized block design. Statistical analysis was performed with the help of OPSTAT software version OPSTAT 1.exe (Hisar, India).

\section{RESULTS AND DISCUSSION}

\section{Proximate composition of raw flour samples}

The statistical data on proximate composition of refined wheat flour, chickpea flour and date powder are presented in Table 1. It is evident from table, values of various parameters studied for different flours used as base material in biscuit preparation varied significantly $(\mathrm{p}<0.05)$. The value for ash content was highest in chickpea flour $(3.30 \%)$ while refined wheat flour displayed the lowest value $(0.3 \%)$. Hefnawy et al. (2012) also observed similar ash content in chickpea flour (3.4\%). However, Osorio-Diaz et al. (2008) observed lower values for the same $(2.7 \%)$. Fat content $(5.81 \%)$ was highest in chickpea flour $(5.40 \%)$ and lowest in date powder $(0.50 \%)$. Jagannadham et al. (2014) reported higher value of fat content for chickpea flour and El-Sharnouby et al. (2012) reported similar value for date powder $(0.40 \%)$. The crude fibre content was highest in date powder $(9.05 \%)$ and lowest in refined wheat flour $(1.25 \%)$. Similar results were obtained by El-Sharnouby et al. $\cdot(\mathbf{2 0 1 2})$. The highest value for protein content was observed in chickpea flour $(21.88 \%)$ while date powder contained lowest protein content $(1.96 \%)$. The observed values of protein are in agreement with the values obtained by Demir et al. (2010) for chickpea flour $(21.88 \%)$ while Ma et al. (2011) reported higher content for dehulled desi chickpea flour $(24.47 \%)$. The carbohydrate content was observed highest for date powder $(74.98 \%)$, followed by refined wheat flour $(74.71 \%)$ and lowest for chickpea flour $(58.77 \%)$. Therefore, it seems logical to supplement refined wheat biscuits with chickpea flour and date powder to increase the nutritional value of biscuits.

Table 2 Functional properties of flours

\begin{tabular}{lccc}
\hline Parameters & RWF & CP & DP \\
\hline Ash $(\%)$ & $0.30 \pm 0.14 \mathrm{a}$ & $3.30 \pm 0.14 \mathrm{c}$ & $2.30 \pm 0.14 \mathrm{~b}$ \\
\hline Moisture $(\%)$ & $12.20 \pm 0.84 \mathrm{c}$ & $8.16 \pm 0.02 \mathrm{a}$ & $11.20 \pm 0.56 \mathrm{~b}$ \\
\hline Fat $(\%)$ & $1.75 \pm 0.07 \mathrm{~b}$ & $5.40 \pm 0.56 \mathrm{c}$ & $0.50 \pm 0.14 \mathrm{a}$ \\
\hline Crude fiber $(\%)$ & $1.25 \pm 0.21 \mathrm{a}$ & $2.50 \pm 0.14 \mathrm{~b}$ & $9.05 \pm 0.21 \mathrm{c}$ \\
\hline Protein $(\%)$ & $9.84 \pm 0.93 \mathrm{~b}$ & $21.87 \pm 0.62 \mathrm{c}$ & $1.96 \pm 0.30 \mathrm{a}$ \\
\hline Carbohydrate $(\%)$ & $74.71 \pm 0.15 \mathrm{~b}$ & $58.77 \pm 0.93 \mathrm{a}$ & $74.98 \pm 0.79 \mathrm{c}$ \\
\hline
\end{tabular}

Legend: Where, $\mathrm{RWF}=$ Refined wheat flour, $\mathrm{CP}=$ Chickpea flour, DP Date powder. The values are average of triplicate analysis with $\pm \mathrm{SD}$. Mean values having different superscript in a row are significantly different $(\mathrm{p}<0.05)$.

\section{Functional properties of flour}

The statistical data regarding functional properties of refined wheat flour, chickpea flour and date powder are presented in Table 2 . 
Table 2 Functional properties of flours

\begin{tabular}{lccc}
\hline Properties & RWF & CP & DP \\
\hline WAC $(\%)$ & $158.05 \pm 3.32^{\mathrm{c}}$ & $114.60 \pm 20.50^{\mathrm{b}}$ & $89.80 \pm 14.14^{\mathrm{a}}$ \\
\hline OAC $(\%)$ & $139.60 \pm 0.70^{\mathrm{c}}$ & $127.25 \pm 2.33^{\mathrm{b}}$ & $112.80 \pm 1.55^{\mathrm{a}}$ \\
\hline BD $(\mathrm{g} / \mathrm{ml})$ & $0.95 \pm 0.04^{\mathrm{c}}$ & $0.73 \pm 0.035^{\mathrm{b}}$ & $0.69 \pm 0.04^{\mathrm{a}}$ \\
\hline SC $(\%)$ & $8.30 \pm 0.14^{\mathrm{c}}$ & $4.71 \pm 0.077^{\mathrm{a}}$ & $6.46 \pm 0.35^{\mathrm{b}}$ \\
\hline Solubility $(\%)$ & $16.85 \pm 3.60^{\mathrm{b}}$ & $10.50 \pm 1.83^{\mathrm{a}}$ & $61.20 \pm 3.25^{\mathrm{c}}$ \\
\hline FC $(\%)$ & $14.54 \pm 0.17^{\mathrm{b}}$ & $28.67 \pm 1.27^{\mathrm{c}}$ & $6.75 \pm 0.65^{\mathrm{a}}$ \\
\hline FS $(\%)$ & $92.65 \pm 0.09^{\mathrm{b}}$ & $97.81 \pm 0.41^{\mathrm{c}}$ & $87.72 \pm 1.50^{\mathrm{a}}$ \\
\hline LGC $(\%)$ & $20 \pm 1.26^{\mathrm{b}}$ & $14 \pm 1.05^{\mathrm{a}}$ & $28 \pm 1.83^{\mathrm{c}}$
\end{tabular}

Legend:Where, $\mathrm{RWF}=$ Refined wheat flour, $\mathrm{CP}=$ Chickpea flour, $\mathrm{DP}=$ Date powder, $\mathrm{WAC}=$ Water absorption capacity, $\mathrm{OAC}=\mathrm{Oil}$ absorption capacity, $\mathrm{BD}=$ bulk density, $\mathrm{SC}=\mathrm{Swelling}$ capacity, FC= Foaming capacity, FS= Foaming stability, LGC= Least gelation concentration The values are average of triplicate analysis with \pm SD. Mean values having different superscript in a row are significantly different $(\mathrm{p}<0.05)$.

\section{Water absorption capacity}

Water absorption capacity (WAC) signifies the amount of water absorbed by a sample when subjected to filtration and centrifugation. Water absorption capacity of flour is a critical function that governs the handling characteristics of flour, its machinability and suitability for use in variety of foods like dough, sausages, processed cheese, soups and bakery products (Adeyeye and Aye, 1998). Water holding capacity differed significantly $(\mathrm{p}<0.05)$ for all flour samples and values varied from $89.8 \%$ to $158 \%$. Highest value was observed for refined wheat flour $(158 \%)$ while lowest value was recorded for date powder $(89.80 \%)$. Higher values of WAC in wheat flour could possibly be due to higher content of hydrophilic components such as protein and soluble fibers present in it. Butt and Batool (2010) attributed the difference in WAC of different flours to the protein concentration, conformational characteristics of protein, and the degree of interaction of protein with water. The relative surface distribution of hydrophilic amino acids and hydrophobic amino acids also affects the WAC of flours (Kuntz, 1971). Other factors have also been ascribed in the previous studies to explain the higher level of WAC of flour like the level of damaged starch, level of amylose fraction and pentosan proportion present in sample (Pauly et al. 2013)

\section{Oil absorption capacity}

All the flours varied significantly $(\mathrm{p}<0.05)$ in their oil absorption capacity. The oil absorption capacity for refined wheat flour $(139.60 \%)$ was recorded higher than chickpea flour $(127.25 \%)$ and date powder $(112.80 \%)$. Similar results were observed by Sanjeewa et al. (2010) for chickpea flour. It is evident from the results that the OAC of refined wheat flour was higher than other flours (date and chickpea) due to inclusion of lower fat levels upon increase of the proportion of other flours. Oil absorption capacity is an important characteristic in bakery products that influences mouth feel, flavor retention, palatability and shelf life of a product (Aremu et al., 2007). The essential component influencing OAC is protein as it contains both hydrophilic and hydrophobic amino acids which interact with lipids in food. The different values of OAC among different flours could be attributed to the variability in the levels of hydrophobic side chains of amino acids which possibly interact with the non polar side chain of the lipid moieties through hydrophobic interaction (Jitngarmkusol et al., 2008).

\section{Bulk density}

Bulk density of flour indicates the weight of a flour sample that can be contained in a fixed volume and is generally expressed as $\mathrm{g} / \mathrm{cm}^{3}$ or $\mathrm{g} / \mathrm{ml}$. It is mainly governed by particle size, internal porosity, and spatial arrangement of particles in the container. This functional property of sample is significant in deciding its packaging requirements and material handling attributes.
Of all the flour samples analyzed, highest value was noted for wheat flour $(0.95)$ followed by chickpea flour (8.30) and date powder (0.69) respectively. Flours with high bulk densities are useful as stabilizers in processed foods (Akubor and Badifu, 2004). Similar results to the present study were observed by Jagannadham et al. (2014) for chickpea flour. Low bulk density is an important requirement in manufacture of infant and weaning foods (Nicole et al., 2010)

\section{Swelling capacity and solubility}

Statistical data reveals significant variation $(\mathrm{p}<0.05)$ among all the flour samples Swelling capacity had highest value for refined wheat flour $(8.35 \%)$ but lowest for chickpea flour $(4.71 \%)$. Swelling power is related to hydration capacity of flour and is measured as weight of water occluded by swollen flour components when flour sample is soaked in water. The relatively higher value of swelling capacity recorded in refined wheat flour could be due to higher amount of soluble component like starch granules and hydrophilic fiber that are expected to bind sufficient amount of water and thereby contributes to increased swelling property. Starch is typically the main component governing the extent of swelling depending upon the variety and category of starch present in flour sample (Schoch, 1964). Similar results were observed by Manickavasagan et al. (2013). Foaming capacity and foaming stability

Foam capacity of sample signifies the extent of interfacial area that can be generated by the protein (Fennema, 2000). Foam capacity varied significantly ( $\mathrm{p}<0.05$ ) among all the flour samples (Table 2) and ranged from $28.67 \%$ to $6.75 \%$. Chickpea displayed the highest value $(28.67 \%)$ and date powder showed lowest value $(6.75 \%)$. Higher value recorded for the parameter in chickpea coincides with higher level of protein in chickpea. Flour with higher protein may be expected to show higher value for foam capacity as large air bubbles can be entrapped by thinner and viscoelastic film of protein, when air is whipped into protein suspension. Similar results to the present study were confirmed by Jagannadham et al. (2014) for chickpea flour and refined wheat flour.

The foam stability (FS) is described as the potency of protein to support itself against gravitational and mechanical forces ${ }^{40}$. Foam stability followed a trend similar to FC with higher values recorded for chickpea flour and lowest for date powder. Similar results to the present study were confirmed by Jagannadham et al. (2014) for chickpea flour and refined wheat flour. As soon as the air bubbles are formed, they tend to collapse and undergo leakage at a fast rate, consequently lowering the foam stability. The level of solubilized protein as well as the content of polar and non-polar lipids in a sample influences the foam stability of protein ${ }^{41}$. Also, foam stability is related to the amount of solubilized protein, and the amount of polar and non-polar lipids in a sample (Zhou et al., 2011).

\section{LGC (Least gelation concentration)}

Least gelation concentration is referred to as that protein concentration at which gel is able to support itself without dropping off the inverted tube. The least gelation concentration varied significantly $(\mathrm{p}<0.05)$ for all flour samples. The value obtained of LGC was highest for date powder (28\%) and lowest for chickpea flour (14\%). Least gelation concentration (LGC) indicates the index of gelation capacity. The differences in the main constituents of the flour i.e. protein, carbohydrates and lipids; and the interaction that occurs between them eventually governs the difference in LGC of flours (Sathe et al., 1983). Gelling ability of the protein ingredient follows an inverse relationship with LGC (Akintayo et al., 1999).

\section{Proximate composition of biscuits}

Table 3 represents proximate composition of biscuits and shows significant difference $(\mathrm{p}<0.05)$ for most of parameters

Table 3 Proximate composition of biscuits

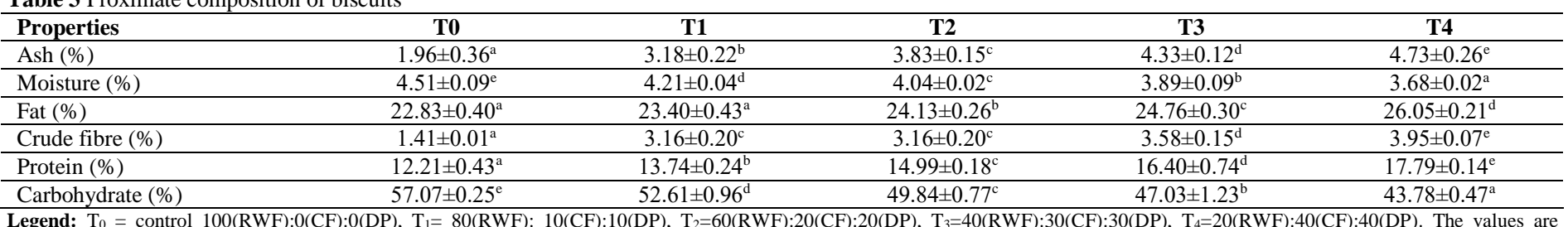

average of triplicate analysis with \pm SD Mean values having different superscript in a row are significantly different $(\mathrm{p}<0.05)$.

Ash content of different biscuit samples increased with the increase in amount of chickpea flour and date powder in basic formulation and varied from 1.96 to $4.73 \%$. The ash content was highest for sample $\mathrm{T}_{4}(4.73 \%)$ and lowest for control $(1.96 \%)$. The increase in ash content of supplemented biscuits might be due to relatively higher mineral content of chickpea flour and date powder compared to refined wheat flour. The fat content was observed highest for sample $\mathrm{T}_{4}(26.05 \%)$ and lowest for sample control $(22.83 \%)$. The increase in fat content of partially substituted biscuit samples might be due to high fat content of chickpea flour $(5.40 \%)$. Similar result for fat content of chickpea flour has also been observed by Jagannadham et $\boldsymbol{a l}$. (2014). Fiber and protein content increased with the corresponding increase in level of substitution of chickpea flour and date powder in the formulation. Fiber content of biscuit samples increased corresponding to increase in date powder due to high fiber content of date powder. Similar results were observed by El-Sharnouby et al. (2012) in biscuits supplemented with 
wheat bran and date palm fruits. The protein content was studied highest in sample $\mathrm{T}_{4}$ and lowest in sample $\mathrm{T}_{1}$. The higher protein content could be attributed to increase in concentration of chickpea flour. Demir et al. (2010) reported that chickpea flour contain large amount of protein (21.88\%). The carbohydrate content of the biscuits was calculated by difference method which involves summing up of all the proximate components on their analysis and subtraction of that sum total from 100. The observed results indicated that the carbohydrate content of biscuits decreased with increased substitution of chickpea flour and date powder in refined wheat flour. The highest value was obtained for sample $\mathrm{T}_{0}$ (57.0\%) while lowest was analyzed for $\mathrm{T}_{4}(43.7 \%)$

\section{Physical properties of biscuits}

The physical attributes of biscuits prepared with refined wheat flour, chickpea flour and date powder blends as well as $100 \%$ refined wheat flour biscuits are presented in Table 4.

Table 4 Physical characteristics of biscuits

\begin{tabular}{|c|c|c|c|c|c|}
\hline Samples & Diameter $(\mathrm{W}, \mathrm{cm})$ & Thickness (T, cm) & Spread ratio (\%) & Volume $\left(\mathrm{cm}^{3}\right)$ & Spread factor (\%) \\
\hline $\mathrm{T}_{0}$ & $5.14 \pm 0.28$ & $0.68 \pm 0.03$ & $7.42 \pm 0.28^{\mathrm{a}}$ & $17.30 \pm 0.86^{\mathrm{b}}$ & $100^{\mathrm{a}}$ \\
\hline $\mathrm{T}_{1}$ & $5.14 \pm 0.12$ & $0.68 \pm 0.02$ & $8.37 \pm 0.25^{\mathrm{b}}$ & $16.28 \pm 0.69^{b}$ & $112.71 \pm 0.12^{\mathrm{b}}$ \\
\hline $\mathrm{T}_{2}$ & $5.15 \pm 0.34$ & $0.67 \pm 0.03$ & $9.53 \pm 0.45^{\mathrm{c}}$ & $14.70 \pm 0.29^{\mathrm{a}}$ & $128.20 \pm 0.31^{\mathrm{c}}$ \\
\hline $\mathrm{T}_{3}$ & $5.14 \pm 0.52$ & $0.67 \pm 0.02$ & $10.26 \pm 0.48^{d}$ & $14.35 \pm 0.43^{\mathrm{a}}$ & $138.40 \pm 0.18^{\mathrm{d}}$ \\
\hline $\mathrm{T}_{4}$ & $5.14 \pm 0.18$ & $0.68 \pm 0.03$ & $11.15 \pm 0.49^{\mathrm{e}}$ & $13.71 \pm 0.70^{\mathrm{a}}$ & $149.73 \pm 0.74^{\mathrm{e}}$ \\
\hline
\end{tabular}

Legend: $\mathrm{T}_{0}=$ control 100(RWF):0(CF):0(DP), $\mathrm{T}_{1}=80(\mathrm{RWF}): 10(\mathrm{CF}): 10(\mathrm{DP}), \mathrm{T}_{2}=60(\mathrm{RWF}): 20(\mathrm{CF}): 20(\mathrm{DP}), \mathrm{T}_{3}=40(\mathrm{RWF}): 30(\mathrm{CF}): 30(\mathrm{DP}), \mathrm{T}_{4}=20(\mathrm{RWF}): 40(\mathrm{CF}): 40(\mathrm{DP})$. The values are average of triplicate analysis with \pm SD. Mean values having different superscript in a column are significantly different $(\mathrm{p}<0.05)$. Non-significant difference

Values for diameter and thickness of different biscuit samples were found to be identical $(\mathrm{p}>0.05)$. The diameter of biscuits ranged from 5.045 to $5.345 \mathrm{~cm}$ However, other attributes like spread ratio and weight of biscuit samples differed significantly $(\mathrm{p}<0.05)$ and spread ratio of biscuits ranged from 7.42 to $11.15 \%$. In case of spread ratio, positive trend was observed with the increase in level of substitution of chickpea flour and date powder, though a reverse trend was observed for weight. Greater content of protein negatively affects the spread ratio of cookies (Gaines and Finney, 1989). However, cookies prepared with higher levels of chickpea flour, despite having high protein content demonstrated higher spread ratio. This anomalous behavior could be attributed to the reduced viscosity chickpea dough and hence the greater spread rate. Reduction in viscosity of dough was observed upon addition of $15 \%$ chickpea flour or more to the mixture of corn flour (Barron and Espinoza, 1993). Lower is the viscosity of dough, faster is the spreading rate of cookies (Hoseney and Rogers, 1994). Spread factor of biscuits ranged from 112.71 to $149.73 \%$. These values of spread factor observed higher as compared to control sample. Spread factor increased with increase in spread ratio it could be due to incorporation of chickpea that increased the lipid content in dough thus contributing to higher spread ratio of biscuits (Gaines and Finney, 1989).

\section{Reduction in sugar level}

Normally, the sugar used in biscuit making is $50 \mathrm{~g}$ per $100 \mathrm{~g}$ of refined wheat flour. In present study, the mentioned sugar level was reduced with the use of date powder as sweetening agent and thus cutting down the amount of sugar required for biscuit manufacture. The sugar level was optimized by substituting date powder up to $20,40,60$ and $80 \%$ with different combinations of sugar and date powder in different treatments. The high level of sugar present in dates was the main factor responsible for different undertaking substitution trials. It was observed that substitution of date powder beyond $30 \%$ level resulted in biscuits with harder texture and darker colour. The biscuits were harder probably due to high fiber content present in date powder and caramelization of sugar resulting in darker colour which was not acceptable. Ahmed et al. (1995) and Vandercook $\boldsymbol{e}$ al. (1980) stated that dates have a high carbohydrate content (70\%), predominated by sugars. Fructose and glucose constitute the main sugars present in date which are present in level one with each other and both are reducing sugars. Generally, consumption of glucose cause instant spike in blood sugar levels as it most rapidly absorbed sugar (Liu et al., 2000). On the other hand, fructose might act to reduce calorie intake compared to fat rich foods as it carries high level of sweetness (twice as much as glucose). On carrying out different trials by substitution of date powder for sugar, it was revealed that sugar may be substituted with date powder and reduction of sugar level to $60 \%$ was possible without any pronounced effect on sensory characteristics of biscuits.

Sensory analysis of biscuits

Table 5 shows the sensory characteristic of biscuits developed from refined wheat flour, chickpea four and date powder in different ratios and $100 \%$ refined wheat flour biscuits.

Table 5 Sensory characteristics of biscuits

\begin{tabular}{lcccc}
\hline Sample & Color & Taste & Texture & $\begin{array}{c}\text { Overall } \\
\text { acceptability }\end{array}$ \\
\hline $\mathrm{T}_{0}$ & $8.29 \pm 0.16^{\mathrm{d}}$ & $8.33 \pm 0.57^{\mathrm{c}}$ & $7.66 \pm 0.57^{\mathrm{c}}$ & $7.99 \pm 0.33^{\mathrm{b}}$ \\
\hline $\mathrm{T}_{1}$ & $7.88 \pm 0.22^{\mathrm{c}}$ & $8.33 \pm 0.32^{\mathrm{c}}$ & $7.33 \pm 0.29^{\mathrm{c}}$ & $7.95 \pm 0.20^{\mathrm{b}}$ \\
\hline $\mathrm{T}_{2}$ & $7.85 \pm 0.37^{\mathrm{c}}$ & $7.33 \pm 0.27^{\mathrm{b}}$ & $7.00 \pm 0.26^{\mathrm{b}}$ & $7.90 \pm 0.19^{\mathrm{b}}$ \\
\hline $\mathrm{T}_{3}$ & $7.00 \pm 0.31^{\mathrm{b}}$ & $7.33 \pm 0.17^{\mathrm{b}}$ & $7.00 \pm 0.20^{\mathrm{b}}$ & $7.80 \pm 0.19^{\mathrm{b}}$ \\
\hline $\mathrm{T}_{4}$ & $6.33 \pm 0.27^{\mathrm{a}}$ & $6.66 \pm 0.27^{\mathrm{a}}$ & $6.33 \pm 0.47^{\mathrm{a}}$ & $6.44 \pm 0.19^{\mathrm{a}}$ \\
\hline
\end{tabular}

Legend: $\quad \mathrm{T}_{0}=\left(\right.$ Control) $\quad 100(\mathrm{RWF}): 0(\mathrm{CF}): 0(\mathrm{DP}), \quad \mathrm{T}_{1}=80(\mathrm{RWF}): 10(\mathrm{CF}): 10(\mathrm{DP})$ $\mathrm{T}_{2}=60(\mathrm{RWF}): 20(\mathrm{CF}): 20(\mathrm{DP}), \mathrm{T}_{3}=40(\mathrm{RWF}): 30(\mathrm{CF}): 30(\mathrm{DP}), \mathrm{T}_{4}=20(\mathrm{RWF}): 40(\mathrm{CF}): 40(\mathrm{DP})$

The values are average of triplicate analysis with \pm SD Mean values having different superscript in a column are significantly different $(\mathrm{p}<0.05)$.
Biscuits were estimated for color, taste, texture and appearance. The highest quality scores (7.99) was obtained for control. The taste of biscuits prepared with up to $60 \%$ substitution of mixture of chickpea flour and date powders for RWF was acceptable and quite close to control in overall acceptability. In terms of nutrient profile, substituted biscuit had higher fat, protein and carbohydrate compared to control biscuits.

The score for texture and overall acceptability decreased with increase in amount of chickpea flour and date powder but was in acceptable range up to $60 \%$ level of substitution of chickpea flour and date powder. Further substitution was not acceptable as samples were harder in comparison to control biscuits. ElSharnouby et al. (2012) reported similar results and stated that incorporation of $30 \%$ of wheat bran and date powder was appropriate for palatable biscuits.

\section{CONCLUSION}

The study concludes that it is possible to prepare biscuits by incorporation of chickpea flour and date powder in refined wheat flour. It was revealed in the study that biscuits with higher protein (up to $33 \%$ ) and fiber content $(153 \%)$ could be prepared by addition of chickpea flour and date powder in the basic formulation. It was found that biscuits prepared with substitution up to $30 \%$ chickpea flour and $30 \%$ date powder were most acceptable in terms of colour, taste and texture. The incorporation of date powder in biscuits may cut down the sugar levels by nearly $60 \%$ compared to commercially available sugar enriched biscuits. These biscuits may be a nutritionally relevant option in the existing wide range of bakery products.

Acknowledgement: Authors acknowledge the Deptt. of Food Technology, Maharishi Dayanad University Rohtak, Haryana, India for technical support during the study.

\section{REFERENCES}

AACC (2000). Approved Methods of the American Association of Cereal Chemists. $10^{\text {th }}$ ed., American Association of Cereal Chemists, St. Paul.

Adeyemi, S. A. O., Ogazi, P. O. 1985. The place of plantain in composite flour. World Health Organization Report No. 522 of Commerce Industry, Lagos State, Nigeria.

Adeyeye, E. I., Aye, P. A. 1998. The effect of sample preparation on proximate composition and the functional properties of African yam bean flours. Journal of Food Science, 75(5), 253-261.

Ahmed, I. A., Ahmed, A. W. K., Robinson, R. K. 1995. Chemical composition of date varieties as influenced by the stage of ripening. Food chemistry, 54(3), 305309. https://doi.org/10.1016/0308-8146(95)00051-j

Akintayo, E. T., Oshodi, A. A., Esuoso, K. O. 1999. Effects of $\mathrm{NaCl}$, ionic strength and $\mathrm{pH}$ on the foaming and gelation of pigeon pea (Cajanus cajan) protein concentrates. Food Chemistry, 66(1), 51-56 https://doi.org/10.1016/s0308-8146(98)00155-1

Akubor, P. I., Badifu, G. I. 2004. Chemical composition, functional properties and baking potential of African breadfruit kernel and wheat flour blends. International Journal of Food Science and Technology, 39(2), 223-229. https://doi.org/10.1046/j.0950-5423.2003.00768.x

AOAC International 1995. Official Methods of Analysis of AOAC International 14th ed., Association of Official Analytical Chemists, Washington DC.

AOAC International. 1999. Official Methods of Analysis of AOAC International. 15th ed., Association of Official Analytical Chemists, Washington DC.

AOAC International. 2000. Official Methods of Analysis of AOAC International. 17th ed., Association of Official Analytical Chemists, Washington DC.

Appel, L. J., Moore, T. J., Obarzanek, E., Vollmer, W. M., Svetkey, L. P., Sacks, F. M., Lin, P. H. 1997. A clinical trial of the effects of dietary patterns on blood pressure. New England Journal of Medicine,336(16), 1117-1124. https://doi.org/10.1097/00006205-199708000-00032 
Aremu, M. O., Olaofe, O., Akintayo, E. T. 2007. Functional properties of some Nigerian varieties of legume seed flours and flour concentration effect on foaming and gelation properties. Journal of Food Technology, 5(2), 109-115. Arshad, M. U., Anjum, F. M., Zahoor, T. 2007. Nutritional assessment of cookies supplemented with defatted wheat germ. Food chemistry, 102(1), 123128. https://doi.org/10.1016/j.foodchem.2006.04.040

BARRÓN, J. M., ESPINOZA, A. 1993. Fortification of maize tortilla with alkalitreated chickpea flour. International Journal of Food Science and Technology, 28(5), 505-511.https://doi.org/10.1111/j.1365-2621.1993.tb01299.x Butt, M. S., Batool, R. 2010. Nutritional and functional properties of some promising legumes protein isolates. Pakistan Journal of Nutrition, 9(4), 373 379.https://doi.org/10.3923/pin.2010.373.379

Coffmann, C. W., Garciaj, V. V. 1977. Functional properties and amino acid content of a protein isolate from mung bean flour. International Journal of Food Science and Technology, 12(5), 473-484. https://doi.org/10.1111/j.13652621.1977.tb00132.x

Demir, B., Bilgicli, N., ELGUeN, A. D. E. M., DEMIR, M. K. (2010). The effect of partial substitution of wheat flour with chickpea flour on the technological nutritional and sensory properties of couscous. Journal of Food Quality, 33(6), 728-741. https://doi.org/10.1111/j.1745-4557.2010.00359.x

El-Sharnouby, G. A., Aleid, S. M., Al-Otaibi, M. M. (2012). Nutritional quality of biscuit supplemented with wheat bran and date palm fruits (Phoenix dactylifera L.). Food and Nutrition Sciences, 3(03), 322. https://doi.org/10.4172/2157-7110.1000402

Fennema, O. R. 2000. Química de los Alimentos. $2^{\text {nd }}$ ed., Zaragoza, Acribia

Gaines, C. S., Finney, P. L. 1989. Effects of selected commercial enzymes on cookie spread and cookie dough consistency. Cereal chemistry (USA).

Hefnawy, T. M. H., El-Shourbagy, G. A., and Ramadan, M. F. 2012. Impact of adding chickpea (Cicer arietinum L.) flour to wheat flour on the rheological properties of toast bread. International Food Research Journal, 19(2), 521-525.

Hoseney, R. C., Rogers, D. E. 1994. Mechanism of sugar functionality in cookies. The science of cookie and cracker production, 1, 203-225.

Iftikhar, F., Kumar, A., Altaf, U. 2015. Development and quality evaluation of cookies fortified with date paste (Phoenix dactylifera L). International Journal of Science, Engineering and Technology, 3, 2348-4098.

Jagannadham, K., Parimalavalli, R., Babu, A. S., Rao, J. S. 2014. A study on comparison between cereal (wheat) and non cereal (chickpea) flou characteristics. International Journal of Current Trend in Research, 3(2), 70-76. Jitngarmkusol, S., Hongsuwankul, J., Tananuwong, K. 2008. Chemical compositions, functional properties, and microstructure of defatted macadamia flours. Food chemistry, 110(1), 23-30 https://doi.org/10.1016/j.foodchem.2008.01.050

Jukanti, A. K., Gaur, P. M., Gowda, C. L. L., Chibbar, R. N. 2012. Nutritiona quality and health benefits of chickpea (Cicer arietinum L.): a review. British Journal of Nutrition, 108(S1), S11-S26. https://doi.org/10.1017/s0007114512000797

Kuntz Jr, I. D. (1971). Hydration of macromolecules. III. Hydration of polypeptides. Journal of the American Chemical Society,93(2), 514-516. https://doi.org/10.1021/ja00731a036

Liu, S., Willett, W. C., Stampfer, M. J., Hu, F. B., Franz, M., Sampson, L., Manson, J. E. 2000. A prospective study of dietary glycemic load, carbohydrate intake, and risk of coronary heart disease in US women-. The American journal of clinical nutrition, 71(6), 1455-1461. https://doi.org/10.1093/ajcn/71.6.1455

Ma, Z., Boye, J. I., Simpson, B. K., Prasher, S. O., Monpetit, D., Malcolmson, L. 2011. Thermal processing effects on the functional properties and microstructure of lentil, chickpea, and pea flours. Food Research International, 44(8), 2534 2544. https://doi.org/10.1016/j.foodres.2010.12.017

Manickavasagan, A., Mathew, T. A., Al-Attabi, Z. H., Al-Zakwani, I. M. 2013 Dates as a substitute for added sugar in traditional foods-A case study with idli. Emirates Journal of Food and Agriculture, 25(11), 899. https://doi.org/10.9755/ejfa.v25i11.14920

Müller, H. P. (1983). The genetic control of seed protein production in legumes. In Seed Proteins (pp. 309-353). Springer, Dordrecht.

Myhara, R. M., Karkalas, J., Taylor, M. S. (1999). The composition of maturing Omani dates. Journal of the Science of Food and Agriculture, 79(11), 1345-1350. https://doi.org/10.1002/(sici)1097-0010(199908)79:11<1345::aidjsfa366>3.0.co;2-v

Narayana, K., Narasinga Rao, M. S. 1982. Functional properties of raw and heat processed winged bean (Psophocarpus tetragonolobus) flour. Journal of Food Science, 47(5), 1534-1538. https://doi.org/10.1111/j.1365-2621.1982.tb04976.x

Nicole, M., Fei, H. Y., Claver, I. P. 2010. Characterization of ready-to-eat composite porridge flours made by soy-maize-sorghum-wheat extrusion cooking $\begin{array}{llll}\text { process. Pakistan Journal of } & \text { Nutrition, 9(2), } & \text { 171-178 }\end{array}$ https://doi.org/10.3923/pjn.2010.171.178

OKAKA, J. C., POTTER, N. N. 1977. Functional and storage properties of cowpea powder-wheat flour blends in breadmaking. Journal of Food Science, 42(3), 828-833. https://doi.org/10.1111/j.1365-2621.1977.tb12614.x

Osorio-Diaz, P., Agama-Acevedo, E., Mendoza-Vinalay, M., Tovar, J., BelloPerez, L. A. 2008. Pasta added with chickpea flour: chemical composition, in vitro starch digestibility and predicted glycemic index. CYTA Journal of Food 6(1), 6-12. https://doi.org/10.1080/11358120809487621

Panda, H. 2004. Herbal Foods and its Medicinal Values. National Institute of Industrial Research.

Pauly, A., Pareyt, B., Lambrecht, M. A., Fierens, E., Delcour, J. A. 2013. Flour from wheat cultivars of varying hardness produces semi-sweet biscuits with varying textural and structural properties. LWT-Food Science and Technology, 53(2), 452-457. https://doi.org/10.1016/j.lwt.2013.03.014

Purushothaman, R., Upadhyaya, H. D., Gaur, P. M., Gowda, C. L. L., Krishnamurthy, L. 2014. Kabuli and desi chickpeas differ in their requirement for reproductive duration. Field Crops Research, 163, 24-31. https://doi.org/10.1016/j.fcr.2014.04.006

Ranganna, S. 1986. Handbook of analysis and quality control for fruit and vegetable products. Tata McGraw-Hill Education.

Sanjeewa, W. T., Wanasundara, J. P., Pietrasik, Z., Shand, P. J. 2010. Characterization of chickpea (Cicer arietinum L.) flours and application in lowfat pork bologna as a model system. Food Research International, 43(2), 617 626. https://doi.org/10.1016/j.foodres.2009.07.024

Sathe, S. K. 1983. Functional properties of black gram (Phaseolus mungo L.) proteins. . LWT-Food Science and Technology, 16, 69-72.

Schoch, T. J. 1964. Swelling Power and Solubility of. Methods in Carbohydrate Chemistry; Whistler, RL, Smith, RJ and Wolfrom, ML eds, 106-108.

Singh, U. 1985. Nutritional quality of chickpea (Cicer arietinum L.): current status and future research needs. Plant Foods for Human Nutrition, 35(4), 339 351. https://doi.org/10.1007/bf01091779

Sosulski, F. W. M. O., Garratt, M. D., Slinkard, A. E. (1976). Functiona properties of ten legume flours. Canadian Institute of Food Technology Journal, 9, 66-69. https://doi.org/10.1016/s0315-5463(76)73614-9

Vandercook, C. E., Hasegawa, S., Maier, V. P. 1980. Dates In Nagy, S. and Shaw, P. E. Tropical and Sub-Tropical Fruits: Composition, Properties and Uses, p. 506-541. Westport, AVI Publishing Company.

Vatsala, C. N., Haridas Rao, P. 1991. Studies on invert syrup for use in biscuits. Journal of food science and technology, 28(3), 149-152.

Zhou, K., Wang, H., Mei, W., Li, X., Luo, Y., Dai, H. 2011. Antioxidant activity of papaya seed extracts. Molecules, 16(8), 6179-6192. https://doi.org/10.3390/molecules 16086179 